\title{
PLACENTAL INTERCHANGE. I. ON THE CONCENTRATION OF CERTAIN NITROGENOUS SUBSTANCES IN THE BLOOD, BEFORE AND AFTER PASSING THROUGH THE PLACENTA
}

\author{
BY W. T. POMMERENKE \\ (From the Department of Obstetrics and Gynecology, University of Rochester, \\ Rochester, New York)
}

(Received for publication April 25, 1936)

Comparative studies on various constituents of the maternal blood before and after its passage through the gravid uterus as well as similar studies on the arterial and venous blood of the fetus have contributed notably to our knowledge of prenatal metabolism and of placental transmission. Evidence is accumulating daily to indicate that the placenta is a complex selective filter which determines what substances shall cross its threshold. Of 73 substances examined by Kehrer (5) in 1907,43 were found to pass through the placenta. This list has been subsequently amplified as is shown by the compilations of Grulee and Bonar (4), Dogliotti (3), and others. Much of the earlier work was done on the lower animals. In the human species, because of obvious restrictions, such studies have been more limited, being confined almost exclusively to observations made at the time of delivery.

Reference will be made only to several of the more recent publications of special interest. In these the reader may find a fairly comprehensive bibliography which need not be duplicated here.

The exchange of lipids in the umbilical circulation at birth has been recently described by Boyd and Wilson (2). There seems to be general agreement, as expressed by the citations of Naeslund (8), Nevinny (9), Lévy-Solal et al. (7), and others, that the concentration of proteins in the maternal circulation is greater than that of the newborn child. Moreover, Naeslund found the protein concentration to be inversely proportional to the water content of the blood. LévySolal et al. discovered that fetal blood contains a proportionately greater amount of albumin over globulin than does the maternal blood. On the basis of studies on rabbits and dogs, Bickenbach and Rupp (1) concluded that peptides do not pass through the placenta, and that albumin must first be broken down by placental ferments to amino acids, before passing through. According to Slemons (11) and Bickenbach and Rupp there is, therefore, no need of assuming that the placenta synthesizes proteins for the fetus. Plass and Matthew (10) and Naeslund (8) are in accord in finding a greater concentration of amino acid in the fetal than in the maternal circulation. Naeslund found that the umbilical arteries carry a greater concentration of amino acids than does the umbilical vein. Bickenbach's findings on this point were inconstant. The nonprotein nitrogen bodies were detected by Plass and Matthew and Naeslund in higher concentration in the fetal than in the maternal circulations. A very slight excess in favor of the maternal circulation was, however, reported by Slemons.

The present communication describes a portion of a more extended investigation of the general problem of placental interchange. While acknowledging our indebtedness to earlier workers for their valued contributions to this mosaic, it seemed desirable for our purpose to obtain composite blood analyses of a fairly large group of normal subjects. For purposes of correlation, this should have a considerable advantage over determinations of single substances in different groups of subjects. It is hoped shortly to compare these basic findings on normal subjects with those having various toxemias or other complications of pregnancy.

\section{METHODS}

Subjects. This study comprises analyses of blood from 40 parturient women, along with those of their respective newborn children. By selecting a fairly large group of individuals, the single variations should be rendered less conspicuous. In every case, a preliminary history and physical 
examination established the essentially normal condition of the patient. The patients were not selected with reference to age, race, or previous dietary habits. Because little food is ordinarily consumed during labor, the values obtained probably approach fasting levels. The blood was studied only in vigorous, normal appearing, newborn children weighing at least 3,000 grams.

Collection of blood. Blood samples were withdrawn without stasis from a cubital vein of the mother, potassium citrate being used as an anticoagulant. In the 40 cases, the samples were almost equally divided between those collected just prior to actual parturition, during parturition, and immediately following parturition. In no instance did more than 6 minutes elapse between the time of collecting the maternal and the fetal blood. Postpartum blood samples were not taken in cases in which a profuse hemorrhage followed the delivery of the child. Almost immediately after the birth of the child, the umbilical cord was severed, and the blood which spurted from one of the umbilical arteries was saved for analysis. Blood from the umbilical vein was likewise promptly obtained from the maternal end of the severed cord.
Analyses. Hematocrit readings were taken after centrifugalization at 3,000 R.P.M. for 30 minutes. Protein determinations (calculated as $N \times 6.25$ ) were made by the micro-Kjeldahl method using selenium oxychloride as a catalyst. The globulins were salted out from the plasma with 22 per cent potassium sulphate. The nonprotein nitrogen was determined by the $\mathrm{Kjeldahl}$ method on the Folin-Wu filtrate. Amino acids were determined by the colorimetric method of Folin. To diminish the incidence of summation of errors, all analyses were run in duplicate from the original samples, and an accuracy of 2 per cent in the check determinations was required.

\section{RESULTS}

The findings of this study are summarized in Table I. The extent of the variations in the values determined for the different substances studied is indicated by the coefficients of variation and by the figures showing the standard deviations. Even when allowance is made for these variations, the arithmetical averages or means can be considered as units and serve to illustrate the selective nature of the placental threshold. The low hematocrit of

TABLE I

Determinations on the blood of 40 normal parturient women, along with those on the blood of their respective newborn children

\begin{tabular}{|c|c|c|c|c|c|c|c|c|c|}
\hline & \multicolumn{3}{|c|}{ Maternal vein } & \multicolumn{3}{|c|}{ Umbilical artery } & \multicolumn{3}{|c|}{ Umbilical vein } \\
\hline & $\underset{\text { mum }}{\text { Maxi- }}$ & Mean & $\underset{\text { mum }}{\text { Mini- }}$ & $\begin{array}{l}\text { Maxi- } \\
\text { mum }\end{array}$ & Mean & $\underset{\text { mum }}{\text { Mini- }}$ & $\underset{\text { mum }}{\text { Maxi- }}$ & Mean & $\underset{\text { mum }}{\text { Mini- }}$ \\
\hline $\begin{array}{l}\text { Hematocrit } \\
\text { Standard deviation } \\
\text { Coefficient of variation, per cent }\end{array}$ & 40.3 & $\begin{array}{r}34.84 \\
2.52 \\
7.23\end{array}$ & 29.1 & 51.2 & $\begin{array}{r}47.0 \\
1.72 \\
3.66\end{array}$ & 43.6 & 50.4 & $\begin{array}{r}45.85 \\
1.61 \\
3.51\end{array}$ & 43.3 \\
\hline $\begin{array}{l}\text { Amino acid nitrogen, mgm. per cent } \\
\text { Standard deviation } \\
\text { Coefficient of variation, per cent }\end{array}$ & 8.1 & $\begin{array}{l}6.87 \\
.479 \\
6.98\end{array}$ & 6.1 & 8.9 & $\begin{array}{l}8.19 \\
.393 \\
4.80\end{array}$ & 7.50 & 8.72 & $\begin{array}{l}8.05 \\
.352 \\
4.38\end{array}$ & 7.30 \\
\hline $\begin{array}{l}\text { Nonprotein nitrogen, mgm. per cent } \\
\text { Standard deviation } \\
\text { Coefficient of variation, per cent }\end{array}$ & 31.5 & $\begin{array}{r}27.25 \\
1.88 \\
6.92\end{array}$ & 23.1 & 30.5 & $\begin{array}{r}28.35 \\
1.47 \\
5.18\end{array}$ & 25.7 & 30.4 & $\begin{array}{r}27.39 \\
1.24 \\
4.54\end{array}$ & 25.2 \\
\hline $\begin{array}{l}\text { Total protein, grams per cent } \\
\text { Standard deviation } \\
\text { Coefficient of variation, per cent }\end{array}$ & 7.21 & $\begin{array}{l}6.55 \\
.294 \\
4.65\end{array}$ & 5.94 & 6.13 & $\begin{array}{l}5.59 \\
.193 \\
3.46\end{array}$ & 5.34 & 6.31 & $\begin{array}{l}5.89 \\
.206 \\
3.50\end{array}$ & 5.46 \\
\hline $\begin{array}{l}\text { Albumin, grams per cent } \\
\text { Standard deviation } \\
\text { Coefficient of variation, per cent }\end{array}$ & 4.59 & $\begin{array}{l}3.73 \\
.367 \\
9.86\end{array}$ & 2.90 & 4.33 & $\begin{array}{c}3.46 \\
.425 \\
12.29\end{array}$ & 2.52 & 4.34 & $\begin{array}{c}3.47 \\
.461 \\
13.28\end{array}$ & 2.58 \\
\hline Globulin, grams per cent & & 2.82 & & & 2.13 & & & 2.42 & \\
\hline Albumin : globulin ratio & & 1.32 & & & 1.63 & & & 1.44 & \\
\hline
\end{tabular}


the mother's blood, so familiarly noted during pregnancy, is obvious. The figures tell only of the concentration and not of the absolute number of red blood cells in the circulation. Keith, Rowntree and Geraghty (6), using vital red, found an increase both in the blood and plasma volumes during pregnancy. This fact must be taken into account in the explanation of the apparent anemia. The relatively high hematocrit of the fetal blood is in accord with the generally known polycythemia of the newborn. The greater volume of erythrocytes in the fetal arterial blood as opposed to that in the fetal venous blood speaks for the withdrawal of fluid from the blood during its passage through the fetus, and the subsequent addition of water by the passage of blood through the placenta. That this interpretation may well apply is suggested by the observation of Naeslund that the venous and arterial blood of the umbilical circulation contains 92.1 per cent and 91.9 per cent of water respectively.

Our findings with reference to the amino acids are in general accord with those of Slemons (11), Plass and Matthew (10), and Naeslund (8). The excess of amino acids in the fetal circulation over that in the maternal circulation would suggest absorption or fixation of these acids by the fetus in a manner similar to that described by Van Slyke. This worker. observed that amino acids after being injected into the circulation are taken up by the tissues until they contain about 10 times as much amino acid as the plasma.

The nonprotein nitrogen bodies were found to be almost equally represented in the venous and arterial circulation of the fetus as well as in the venous circulation of the mother. This close relationship is hardly incidental, for as waste products they can be expected to diffuse readily through the fetal tissues as well as through the placenta. The slight, though detectable, excess of nonprotein nitrogen in the fetal circulation over that in the maternal circulation may possibly be explained on the basis of a more active metabolism.

The concentration of the maternal plasma proteins is noted to be definitely higher than that of the fetus, this observation confirming that of Naeslund (8), Nevinny (9), and Lévy-Solal et al. (7). This certainly speaks against any free passage of protein through the placental barrier. Our findings show a perceptible excess of plasma proteins in favor of the circulation of the umbilical vein over that of the umbilical arteries, the mean values being 5.89 grams per cent versus 5.59 grams per cent, respectively. Naeslund and Nevinny, in contradistinction, found more protein in the umbilical arterial circulation. It must be admitted, however, that in our series of 40 cases, 11 showed a slightly higher value in the arterial than in the venous blood. The same relationship, with reference to the concentrations of the total plasma proteins in the circulations of the mother, the umbilical vein, and the umbilical artery, is noted to apply to their respective concentrations of albumin and globulin. The globulin values were determined by subtracting the albumins from the total proteins. Hence the correction or variation factors of the globulins are dependent on those of the albumins and total proteins. The albumin:globulin ratios of the circulation of the umbilical vessels would indicate that the plasma of the fetus is richer in albumin than is that of the mother.

\section{SUMMARY}

Generalizations concerning the passage of substances through the placenta are hazardous without reference to a consideration of specific substances. The evidence would indicate that the placenta is teleologically sensitive in its selection of substances to be added to or withdrawn from the fetal circulation. The nonprotein nitrogen bodies apparently pass through the placenta in either direction according to the rules of simple diffusion. The small size of the amino acid molecules will permit of their passage to the fetus where they are retained in excess. The large molecules of the albumins and globulins do not seem to pass through the placenta to the fetus, and it is assumed that these are synthesized from the amino acids by the fetal tissues. In the interpretations of variations in the relative amounts of substances found in the circulation on either side of the placenta, and between the venous and arterial circulations of the fetus, one must remember to distinguish between the matter of absolute quantity and of concentration of these substances. The significant phenomena associated with water 
metabolism and content of the blood must always be regarded in the explanation of results.

The author wishes to express his thanks to Miss Jane Dye for the statistical analyses of data as expressed by her calculations of the deviations from the mean and of the coefficients of variation. i. . s.

\section{BIBLIOGRAPHY}

1. Bickenbach, W., and Rupp, H., Die Plazentare Aufnahme von Eiweissbausteinen für die Frucht. Ztschr. f. Geburtsh. u. Gynäk., 1932, 103, 170.

2. Boyd, E. M., and Wilson, K. M., The exchange of lipids in the umbilical circulation at birth. J. Clin. Invest., 1935, 14, 7.

3. Dogliotti, V., Modificazioni Chimiche del Sangue del Feto nella Placenta e Confronto tra Sangue Fetale e Sangue Materno. Riv. ital. di ginec., 1934, 16, 667.

4. Grulee, C. G., and Bonar, B. E., The New Born;
Diseases and Abnormalities, Physiology and Care. D. Appleton \& Co., New York, 1926.

5. Kehrer, Cited by Slemons (11).

6. Keith, N. M., Rowntree, L. G., and Geraghty, J. T., A method for the determination of plasma and blood volume. Arch. Int. Med., 1915, 16, 547.

7. Lévy-Solal, E., Dalsace, J., and Gutman, C., Recherches Biochimiques sur la Rôle du Placenta. Compt. rend. Soc. de biol., 1934, 115, 269.

8. Naeslund, John, Untersuchungen über den Ubergang N-haltiger Stoffe vom Fötus auf die Mutter. I and II. Acta obst. et gynec. Scandinav., 1931, 11, 293 and 474.

9. Nevinny, H., Über die Blutstruktur bie Mutter und Kind. Arch. f. Gynäk., 1930-31, 144, 560.

10. Plass, E. D., with the assistance of Matthew, C. W., Placental transmission. III. The amino acids, nonprotein nitrogen, urea, and uric acid in fetal and maternal whole blood, plasma, and corpuscles. Bull. Johns Hopkins Hosp., 1925, 36, 393.

11. Slemons, J. M. The Nutrition of the Fetus. Yale University Press, New Haven, 1919. 